\title{
EVALUASI KEGIATAN POKJA (KELOMPOK KERJA) LOKALISASI DALAM PENCEGAHAN IMS DAN HIV-AIDS DI LOKALISASI SLOROK SUMBER PUCUNG KABUPATEN MALANG TAHUN 2015
}

\author{
Nur Zad Malikha ${ }^{1}$ \\ email: ikkamalikha@yahoo.com \\ ${ }^{1}$ Akademi Kebidanan Wijaya Kusuma Malang, Jl. Tlogowaru Malang.Telp (0341) 7500358
}

\begin{abstract}
Abstrak
Di wilayah kerja Puskesmas Sumberpucung terdapat 3 Lokalisasi yang memiliki POKJA (kelompok Kerja) dalam pencegahan IMS dan HIV-AIDS di Lokalisasi.Pada laporan cakupan pencapaian kunjungan klinik IMS tahun 2014-2015 didapatkan di Lokalisasi Slorok di dapatkan peningkatan Kasus IMS (2\%).Tujuan penelitian untuk mengevaluasi Kegiatan POKJA Lokalisasi dalam Pencegahan IMS dan HIV-AIDS di Lokalisasi Slorok Sumberpucung Kabupaten Malang Tahun 2015.

Penelitian ini menggunakan pendekatan kualitatif dengan rancangan studi kasus. Jumlah subyek penelitian di lokalisasi Slorokadalah 4 orang dan informan triangulasi sebanyak 5 orang. Pengumpulan data dengan wawancara mendalam mengunakan kuesioner yang berisi pertanyaan terbuka. Analis is da ta menggunakan content analysis.

Hasil Penelitian pada pendidikan dan penyuluhan POKJA: setiap tahun dilakukan pelatihan POKJA dan setiap bulan di lakukan pertemuan POKJA rutin yang didalamnya juga membahas permasalahan POKJA dilokalisasi, sedangkan akses kondom: lokalisasi slorok sudah melakukan secara mandiri walaupun terkadang masih mendapat dari LSM dan puskesmas akan tetapi tidak ada evalu asi tentang penggunaannya, untuk pemberdayaan kader: kader WPS lokalisasi SLorok hanya sebagai koordinator mengumpulkan WPS lain saat akan ada pertemuan dan pemeriksaan dan untuk pemeriksaan kesehatan rutin keklinik IMS: dilakukan sebulan sekali dan tes darah setiap 3 bulan, jika terdapat WPS yang IMS maka puskesmas akan memberitahukan hasil kepada POKJA untuk pemantau an konsumsi obat dan dijadwalkan pemeriksaan ulang minggu berikutnya,sedangkan jika ada WPS HIV maka puskesmas akan langsung ke LSM karena menganggap POKJA masih memiliki stigma yang tinggi kepada ODHA.
\end{abstract}

Kata kunci: Pencegahan IMS dan HIV-AIDS di Lokalisasi.

\section{Pendahuluan}

Masalah HIV dan AIDS adalah masalah kesehatan masyarakat yang memerlukan perhatian yang sangat serius. Ini terlihat dari apabila dilihat jumlah kasus AIDS yang dilaporkan setiap tahunnya sangat meningkat secara signifikan. ${ }^{1}$

Jika dilihat cara penularannya, proporsi penularan melalui hubungan seksual (baik heteroseksual maupun homoseksual) sangat mendominasi dibandingkan dengan melalui jarum suntik dan ada sebagian kecil lainnya tertular melalui ibu dan anak (kehamilan), transfusi darah dan melalui pajanan saat bekerja. Melihat cukup besar peluang HIV ditularkan melalui hubungan seksual, maka hubungan berganti-ganti pasangan merupakan faktor khusus yang perlu diwaspadai. Seks komersial telah menjadi sebuah faktor yang penting di dalam penyebar infeksi HIV, khususnya di kawasan Asia ${ }^{2}$.

Kabupaten Malang sebagai salah satu kabupaten terbesar di Jawa Timur setelah Surabaya,yang berbatasan langsung dengan kota besar lainnya seperti Surabaya dan Kota Malang. Kondisi ini mempengaruhi akan keberadaan Wanita Pekerja Seks Komersial (WPS) dengan adanya 4 lokalisasi ( Suko, Kebobang, Slorok dan Gondanglegi). Lokalisasi Slorok merupakan salah satu lokalisasi yang ada di Kabupaten Malang dengan jumlah WPS sebanyak 72 orang yang menempati 14 wisma $^{3}$. Pembentukan POKJA di Lokalisasi Slorok sudah sesuai dengan aturan yang sudah di tetapkan oleh KPAN dengan sebelum melakukan tugasnya POKJA diberikan pelatihan terlebih dahulu tentang segala hal yang berhubungan dengan tugasnya sebagai POKJA di Lokalisasi. 
Pada laporan cakupan pencapaian kunjungan klinik IMS di 3 Lokalisasi yang ada di Puskesmas Sumberpucung yaitu didapatkan di Lokalisasi Suko pada tahun 2013 angka IMS 26\% dari kunjungan di Klinik IMS sedangkan pada Januari - Juni 2014 di dapatkan 682 Kunjungan dan terdapat 152 Kasus IMS $(22 \%)$, di Lokalisasi Slorok pada tahun 2013 angka IMS 37\% sedangkan pada Januari - Juni 2014 di dapatkan Slorok Januari -Juni 2014 di dapatkan 375 kunjungan dan terdapat 147 Kasus IMS (39\%) dan Lokalisasi Kebobang pada tahun 2013 angka IMS 30\% dari kunjungan di Klinik IMS sedangkan pada Januari - Juni 2014 di dapatkan 292 Kunjungan dan terdapat 85 Kasus IMS (29\%). ${ }^{4}$

Penelitian ini bertujuan untuk Mengevaluasi Kegiatan POKJA Lokalisasi dalam pencegahan IMS dan HIV-AIDS di Lokalisasi Slorok Kabupaten Malang Tahun 2015.

\section{Metode Penelitian}

Metode yang dipakai dalam penelitian ini adalah Penelitian Kuantitatif. Subyek penelitian pada penelitian kuantitatif ini adalah POKJA di lokalisasi Slorok Kabupaten Malang tahun 2015 dari jumlah estimasi populasi sekitar 4 orang yang terdiri dari mucikari, dan warga daerah lokalisasi yang berperan sebagai penjaga warung dan keamanan. Informan lain dalam penelitian yang digunakan untuk triangulasi data, adalah 2 orang tenaga kesehatan di Puskesmas Sumberpucung, 1 orang LSM yang menaungi program dan 1 orang WPS, 1 orang kader WPS dan 1 orang mucikari. Tehnik pengambilan data dengan wawancara mendalam.

\section{Hasil dan Pembahasan}

Tabel 1. Karakteristik Responden

\begin{tabular}{lcc}
\hline KarakteristikResponden & jumlah & $\%$ \\
\hline Umur & 3 & 75 \\
$48-53$ tahun & 1 & 25 \\
$54-60$ tahun & & \\
Jenis Kelamin & 3 & 75 \\
Laki - Laki & 1 & 25 \\
Perempuan & & \\
Pendidikan &
\end{tabular}

SD

3

75

SMP

1

Lama kerja di lokalisasi

6-10 tahun

2

50

$11-15$ tahun

2

50

Pekerjaan di Lokalisasi

Mucikari

Penjaga warung

Keamanan

25

50

Lama menjadi POKJA

$1-5$ tahun

$6-10$ tahun

75

25

Hasil penelitian pada 4 subyek penelitian diketahui bahwa sebelum melakukan tugasnya sebagai POKJA dalam bidang pendidikan dan penyuluhan kesehatan, 4 subyek penelitian telah mendapatkan pelatihan terlebih dahulu dari LSM Paramitra. Dalam pelatihan bukan hanya sekedar diberikan materi, tetapi juga dilakukan diskusi terkait dengan permasalahan kesehatan di lokalisasi yang belum dipahami dengan benar oleh anggota POKJA. Selain itu pemberian informasi kesehatan juga diberikan saat pertemuan rutin POKJA setiap bulannya jika ada informasi kesehatan terbaru. Berdasarkan hasil penelitian dari Zahra (2007), dengan di adakannya POKJA maka terdapat perubahan sikap dan pengetahuan WPS terhadap pencegahan IMS dan HIV/AIDS di Lokalisasi dengan dilakukannya penyuluhan secara formal oleh LSM dan pendidikan kesehatan secara informal oleh POKJA sehingga WPS juga menyampaikan informasi kesehatan kepada pelanggan. ${ }^{5}$

akses kondom dilokalisasi sudah stabil, bahkan sudah cenderung mandiri yang mana di dalam lokalisasi sudah terjadi proses ekonomi terhadap pendistribusian kondom dan sudah tidak menggantungkan diri pada kondom gratis dari puskesmas dan LSM sehingga POKJA sudah melakukan koordinasi dengan distributor kondom merk tertentu, tampak juga di lokalisasi setiap wisma terdapat gambar dari merk kondom tersebut.

Menurut 4 subyek penelitian dinyatakan bahwa didalam lokalisasi terdapat kebijakan terkait dengan kondom yaitu setiap WPS diwajibkan untuk 
membeli kondom 6 buah setiap minggu dan apabila kehabisan WPS bisa membeli lagi ke POKJA. Tetapi dinyatakan oleh POKJA bahwa tidak pernah sekalipun WPS membeli kondom tambahan pada POKJA meskipun tamunya lebih dari 6 orang dalam 1 minggu, terkait dengan hal ini sanksi yang berkaitan tentang pemakaian kondom dilokalisasi sangat rendah, jika terdapat WPS yang melakukan transaksi seksual tanpa menggunakan kondom oleh mucikari dan POKJA akan dikembalikan ke masingmasing WPS terkait dengan akibat penyakit dari perbuatannya. Menurut hasil penelitian Zahra (2007), sudah adanya POKJA yang memfasilitasi distribusi kondom dan pengetahuan WPS yang cukup baik tentang pencegahan IMS dan HIV/AIDS sehingga WPS berusaha untuk membujuk dan memotivasi pelanggan, tetapi pelanggan tetap bersikeras untuk tidak menggunakan kondom walaupun sudah mengetahui resikonya, sehingga karena factor ekonomi WPS lebih memilih pelanggan daripada menggunakan kondom. ${ }^{5}$

Kader WPS di bentuk oleh LSM paramitra yang memiliki peran untuk menyampaikan informasi kepada sesama WPS di masing-masing wismanya tentang kesehatan reproduksi, yang sebelumnya kader WPS diberikan pelatihan tentang kesehatan reproduksi. Sehingga dalam pemilihan kader WPS memiliki criteria antara lain WPS tersebut merupakan penghuni lama di wisma tersebut dan memiliki pengaruh terhadap WPS lainnya. Akan tetapi dalam pelaksanaannya, peran kader dilokalisasi Slorok ini hanya sebatas mengkoordinir WPS lain saat akan diadakan pertemuan dan pemeriksaan. Berdasarkan hasil penelitian Zahra, dalam bidang pemberdayaan kader disebutkan tugas kader antara lain: memberikan informasi kepada WPS baru di lokalisasi, menjangkau pelanggan, merujuk teman sebaya WPS untuk mengikuti pemeriksaan dan rutin mengikuti pertemuan. ${ }^{5}$

setiap WPS diharuskan untuk melakukan pemeriksaan rutin IMS sebulan sekali dan tes darah 3 bulan sekali. Dalam pelaksanaannya pemeriksaan IMS dilakukan setiap hari rabu, jika ada WPS yang berhalangan ikut maka WPS tersebut harus tetap datang untuk pemeriksaan kesehatan pada minggu berikutnya.

Jika didapatkan WPS yang menderita IMS maka akan diberitahukan kepada POKJA untuk diobservasi dalam konsumsi obat dan diedukasi tentang penggunaan kondom, untuk minggu berikutnya harus ke puskesmas lagi melakukan pemeriksaan ulang sampai dinyatakan sembuh dari IMS. Jika didapatkan WPS reaktif HIV-AIDS maka pihak puskesmas akan menawarkan kepada WPS untuk pendampingan kerumah sakit dan jika sudah timbul infeksi oportunistik akan disampaikan kepada manajemen kasus dari LSM untuk periksa CD4 di Rumah sakit.

Menurut penelitian Zahra, dalam bidang pemeriksaan kesehatan tujuan dari POKJA yaitu menciptakan lingkungan yang kondusif bebas IMS dan HIV/AIDS dapat tercapai. Maka dengan diadakannya pemeriksaan kesehatan ini WPS dapat mengerti kondisi kesehatan mereka secara medis, dan segera mendapatkan penanganan jika mengalami suatu masalah kesehatan. ${ }^{5}$

\section{Kesimpulan}

Hasil kegiatan POKJA dilokalisasi dapat dipaparkan sebagai berikut: akses kondom lancar tetapi dalam penggunaannya belum dapat $100 \%$ dikarenakan proses negosiasi yang rendah dengan pelanggan dan factor ekonomi, kunjungan ke klinik IMS rutin tetapi dalam hal status HIV WPS tidak di sampaikan kepada POKJA tetapi langsung kepada LSM karena puskesmas masih menganggap POKJA memiliki stigma terhadap HIV-AIDS, pengetahuan WPS tentang kesehatan selalu update baik itu disampaikan oleh POKJA, LSM maupun pihak dari puskesmas, peran Kader WPS belum sesuai dengan tujuan pendiriannya yang mn seharusnya kader WPS memiliki tugas dalam penyampaian informasi kepada WPS dan pendampingan WPS yang sakit akan tetapi dilokalisasi kader WPS hanya membantu POKJA dalam koordinasi WPS lain saat akan diadakan pertemuan dan pemeriksaan.

Selalu ada angka IMS tiap bulannya dikarenakan ketidak teraturan dalam pemakaian kondom karena proses negosiasi yang rendah dengan pelanggan terhadap 
pemakaian kondom, selain itu juga peraturan di lokalisasi penerapannya masih sangat lemah terutama dalam hal emakaian kondom karena POKJA menganggap akibat dari perilaku WPS tersebut akan diterima oleh WPS itu sendiri.

\section{Daftar Pustaka}

[1] Arija, Zahra Asri. Keefektifan Program POKJA (Kelompok Kerja) penanggulangan HIV/AIDS di Lokalisasi Gondanglegi Wetan Kabupaten Malang Tahun 2007. Universitas Negeri Malang. 2007.

[2] Elizabeth P, Chetwynd J, and Reed A. Control and Condoms in Commercial Sex: Client Perspective. Sociology of Health and Illness. 1997; 19: 228-243.

[3] Kartono K. Patologi Sosial. Raja Grafindo Persada. Jakarta. 2001.

[4] LSM Paramitra. Laporan Tahunan Program LSM Paramitra Malang Tahun 2010: Penanggulangan HIV\&AIDS dengan Pendekatan Komprehensif. LSM Paramitra Malang. Malang. 2010.

[5] Puskesmas Sumberpucung. Capaian Lokalisasi Slorok. Puskesmas Sumberpucung. Sumberpucung. 2014. 